\title{
Evaluation of Foxtail Millet [Setaria italica (L.) Beauv.] Germplasm for Lysine Content
}

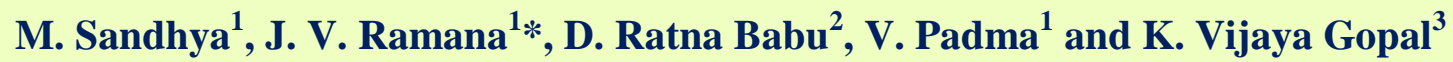 \\ ${ }^{1}$ Department of Molecular Biology and Biotechnology, ${ }^{2}$ Department of Genetics and Plant \\ Breeding, ${ }^{3}$ Department of Microbiology, Advanced Post Graduate Centre, Acharya NG Ranga \\ Agricultural University, Lam, Guntur-522034, India \\ *Corresponding author
}

\section{A B S T R A C T}

\section{Keywords}

Foxtail millet, Lysine, Essential amino acid and Millets

Article Info

Accepted:

12 October 2020

Available Online:

10 November 2020
Foxtail millet (Setaria italica (L.) Beauv.) is a potential climate resilient, C4 Panicoid crop. It is commonly known as Italian millet and is a staple food crop grown in some parts of China, India and Japan. Nutrient composition of millets is higher than the average nutrient composition in major cereals (Muthamilarasan and Prasad, 2015). Research studies are lagging behind in nutrient profiling of millets. Hence, the present study was carried out with one hundred genotypes of foxtail millet procured from ICRISAT mini core collection (Upadhyaya et al., 2011) for Lysine content. The range of values for these parameters ranged from 0.49-2.45 respectively, ISe $1610(0.49 \mathrm{~g} / 100 \mathrm{~g}$ of protein) recorded least amount of Lysine whereas ISe 1187 recorded highest amount of Lysine $(2.45 \mathrm{~g} / 100 \mathrm{~g}$ of protein). The study also reveals great variability existing among the collection of Italian millet accessions for Lysine that can be exploited to improve the cultivars to meet the nutritional requirements of humans.

\section{Introduction}

Nutrient superiority of millets in terms of its non-gluten protein, high fibre content, minerals, vitamins and antioxidants is firmly established over non-millet cereals, and hence these are popularized as 'nutricereals'. Foxtail millet (Setaria italica (L.) Beauv.) is a good source of micro and macronutrients with high nutraceutical and antioxidant properties. It contains good amount of proteins, dietary fibers, vitamins, minerals, anti-oxidants and non-starchy polysaccharides with low glycemic index, when compared to major cereals (Taylor et al., 2006; Amadou et al., 2013; Muthamilarasan and Prasad, 2015). It is a valuable model to exploit phytonutrient pathways of millets. It has been suggested to 
use foxtail millet protein as a food component to fight type 2 diabetes and cardiovascular diseases (Choi et al., 2005). It was reported that Black and grey foxtail millet grains often have high amounts of protein along with high amounts of this indispensable aminoacid Lysine (He et al., 2002). Lysine is an essential aminoacid (EAA) which cannot be synthesized by humans and should be supplied from food sources. Hence, profiling of available food sources for Lysine is of prime value. This study helps in identifying the genotypes with the essential amino acid lysine, which is said to be limiting in millets and cereals. This helps in improving the cultivars by exploiting required genotypes and making its cultivation remunerative to the farmers.

\section{Materials and Methods}

The experiment was conducted during kharif, 2017 at Regional Agricultural Research Station, Lam, Guntur, Andhra Pradesh, which is located at $16.100 \mathrm{~N}$ latitude, $28.290 \mathrm{E}$ longitude and $31.5 \mathrm{~m}$ altitude. One hundred germplasm accessions of foxtail millet procured from ICRISAT were laid out in Augmented RCBD and the seed samples of their germplasm were used for estimation of Lysine. Lysine was estimated as per the following procedure given by Theymoli and Sadasivam (1987). Firstly, enzymatic hydrolysis was done with papain solution resulting in liberation of free amino acids and low molecular weight peptides. The amino groups of the free amino acids were blocked with copper, while the $\varepsilon$-amino group of lysine remains free. The $\varepsilon$-dinitropyridyl derivative of lysine was formed upon reaction with 2-chloro-3, 5-dinitropyridine. Extraction of the reaction mixture with ethyl acetate removes the excess of 2-chloro-3, 5dinitropyridine, leaving an aqueous solution of $\varepsilon$-dinitropyridyl-lysine. The absorbance of this solution was measured at $390 \mathrm{~nm}$.

\section{Results and Discussion}

Millets and other cereal grains are deficient in some of the indispensable amino acids such as Lysine (Geervani and Eggum, 1989). Vadivoo et al., 1998 reported that prosomillet grains are richer in essential amino acids and contain about $3.3 \mathrm{~g} / \mathrm{kg}$ of lysine when compared with that of other millets. The lysine content in foxtail millet germplasm ranges from $0.20 \%$ to $0.30 \%$ (Zhu et al., 2004, Tian et al., 2009). Some of the lysine rich foxtail millet cultivars (Gouweisu, 27531; Gouweisu, 27510; Xiomi, 27516) were reported by Zhu et al., 2004. He et al., 2002 reported that Black and grey seeded foxtail millet germplasm have higher lysine content. Kamara et al., 2009 reported the range from $11.39-11.92 \mathrm{~g} / 100 \mathrm{~g}$ of defatted foxtail millet flour and their aminoacid profiling revealed to contain higher amount of lysine in foxtail millet protein. Chandel et al., 2014 reported the mean value of lysine for Foxtail millet as $2.42 \mathrm{~g} / 16 \mathrm{~g}$ of $\mathrm{N}$ (RAU-8 genotype) which was higher when he compared it with that of Little millet and Finger millet.

In our present study one hundred germplasm accessions of foxtail millet were assessed for essential aminoacid Lysine (g/100g of protein) content. The analysis of variance (ANOVA) revealed significant difference at $1 \%$ level for the trait studied (Table 1). The Range, mean values, SD, SE, CV\%, obtained and the genotypes with Mean + SD for the quality parameter is presented in Table 2, The range of values obtained on analysis is $0.49 \mathrm{~g} / 100 \mathrm{~g}$ of protein in ISe 1610 where as the highest amount of $2.45 \mathrm{~g} / 100 \mathrm{~g}$ of protein was recorded for ISe 1187 with the mean value of $1.48 \mathrm{~g} / 100 \mathrm{~g}$ of protein. This shows that there are 22 genotypes which are above mean+SD values for Lysine which can be exploited for crop improvement and direct supplementation with other cereal based foods. The mean value of each genotype for the Lysine content is given in Table 3. 
Table.1 Analysis of variance (ANOVA) for Lysine in foxtail millet [Setaria italic (L.) Beauv.]

\begin{tabular}{|c|c|c|}
\hline Sources of variations & d.f & $\begin{array}{c}\text { Lysine } \\
\text { (g/100g of protein) } \\
\text { Mean sum of squares }\end{array}$ \\
\hline Treatment & 103 & $\mathbf{0 . 2 6} * *$ \\
\hline Treatment: Check & 3 & $\mathbf{0 . 1} * *$ \\
\hline Treatment: Test vs. Check & 1 & $\mathbf{1 . 4 2} * *$ \\
\hline Treatment: Test & 99 & $\mathbf{0 . 2 6} * *$ \\
\hline Blocks & 3 & $\mathbf{0 . 2 7} * *$ \\
\hline Error & $\mathbf{9}$ & $\mathbf{0 . 0 1}$ \\
\hline
\end{tabular}

* Significant at $5 \%$ level

** Significant at $1 \%$ level

Table.2 Mean Performance, Range, SD, SE, CV\% and the accessions with high Mean+SD for Lysine

\begin{tabular}{|c|c|c|c|c|c|c|c|c|}
\hline \multirow[t]{2}{*}{ S.No. } & \multirow[t]{2}{*}{ Parameters } & \multirow[t]{2}{*}{ Mean } & \multirow[t]{2}{*}{ Range } & \multirow{2}{*}{$\begin{array}{c}\text { Std. } \\
\text { Devia } \\
\text { tion }\end{array}$} & \multirow{2}{*}{$\begin{array}{l}\text { Std. } \\
\text { Error }\end{array}$} & \multirow[t]{2}{*}{ CV\% } & \multicolumn{2}{|c|}{ Number \& identified Genotypes } \\
\hline & & & & & & & $\begin{array}{l}\text { No. of } \\
\text { genotypes }\end{array}$ & $\begin{array}{c}\text { Best Genotypes } \\
\text { High i.e }>(\text { Mean+SD) }\end{array}$ \\
\hline 1 & $\begin{array}{c}\text { Lysine }(\mathrm{g} / 100 \\
\text { g protein) }\end{array}$ & 1.48 & $\begin{array}{l}0.49- \\
2.45\end{array}$ & 0.50 & 0.05 & 33.80 & 22 & $\begin{array}{c}\text { ISe } 1181, \text { ISe } 1227, \text { ISe } 1258, \\
\text { ISe } 1286, \text { ISe } 1302, \text { ISe } 1338, \\
\text { ISe } 1547, \text { ISe } 1575, \text { ISe } 1685, \\
\text { ISe } 1704 \text {, ISe } 1789, \text { Ise } 751 \text {, Ise } \\
\text { 771, Ise } 1118, \text { Ise } 1134, \text { Ise } \\
1137, \text { Ise } 1187, \text { Ise } 1201, \text { Ise } \\
\text { 1312, Ise } 1320, \text { Ise } 1387, \text { Ise } \\
1563\end{array}$ \\
\hline
\end{tabular}

Table.3 Mean performance of 100 foxtail millet [Setaria italica(L.) Beauv.] Genotypes for Lysine content

\begin{tabular}{|l|l|c|l|l|c|}
\hline S.No. & Genotype & $\begin{array}{c}\text { Lysine (g/100g } \\
\text { protein) }\end{array}$ & S.No. & Genotype & $\begin{array}{l}\text { Lysine } \\
\text { protein) }\end{array}$ \\
\hline $\mathbf{1}$ & Ise237 $3700 g$ \\
\hline $\mathbf{2}$ & ISe 403 & 1.39 & 53 & Ise 267 & 0.72 \\
\hline $\mathbf{3}$ & ISe 710 & 0.52 & 54 & Ise 289 & 1.15 \\
\hline $\mathbf{4}$ & ISe 735 & 1.63 & 55 & Ise 388 & 1.19 \\
\hline $\mathbf{5}$ & ISe 748 & 1.54 & 56 & Ise 398 & 0.83 \\
\hline $\mathbf{6}$ & ISe 783 & 0.59 & 58 & Ise 480 & 1.27 \\
\hline $\mathbf{7}$ & ISe 792 & 1.05 & 59 & Ise 663 & 0.94 \\
\hline $\mathbf{8}$ & ISe 827 & 0.94 & 60 & Ise 719 & 1.22 \\
\hline $\mathbf{9}$ & ISe 914 & 1.08 & 61 & Ise 746 & 1.33 \\
\hline $\mathbf{1 0}$ & ISe 963 & 0.61 & 62 & Ise 751 & 1.35 \\
\hline $\mathbf{1 1}$ & ISe 1067 & 1.65 & 63 & Ise 758 & 1.52 \\
\hline
\end{tabular}




\begin{tabular}{|c|c|c|c|c|c|}
\hline 12 & ISe 1136 & 1.28 & 64 & Ise 771 & 2.32 \\
\hline 13 & ISe 1161 & 1.82 & 65 & Ise 828 & 0.94 \\
\hline 14 & ISe 1163 & 1.59 & 66 & Ise 842 & 0.83 \\
\hline 15 & ISe 1177 & 1.5 & 67 & Ise 846 & 0.62 \\
\hline 16 & ISe 1181 & 2.35 & 68 & Ise 900 & 0.69 \\
\hline 17 & ISe 1227 & 2.07 & 69 & Ise 969 & 0.83 \\
\hline 18 & ISe 1234 & 1.85 & 70 & Ise 999 & 1.3 \\
\hline 19 & ISe 1258 & 1.99 & 71 & Ise 1009 & 1.42 \\
\hline 20 & ISe 1286 & 2.3 & 72 & Ise 1037 & 1.91 \\
\hline 21 & ISe 1302 & 2.04 & 73 & Ise 1118 & 2.15 \\
\hline 22 & ISe 1305 & 1.72 & 74 & Ise 1119 & 1.65 \\
\hline 23 & ISe 1332 & 1.64 & 75 & Ise 1129 & 1.77 \\
\hline 24 & ISe 1338 & 2.07 & 76 & Ise 1134 & 2.04 \\
\hline 25 & ISe 1460 & 0.83 & 77 & Ise 1137 & 2.27 \\
\hline 26 & ISe 1474 & 0.87 & 78 & Ise 1151 & 1.74 \\
\hline 27 & ISe 1547 & 2.12 & 79 & Ise 1162 & 1.52 \\
\hline 28 & ISe 1575 & 2.24 & 80 & Ise 1187 & 2.45 \\
\hline 29 & ISe 1597 & 0.61 & 81 & Ise 1201 & 2.08 \\
\hline 30 & ISe 869 & 1.43 & 82 & Ise 1209 & 1.19 \\
\hline 31 & ISe 1666 & 1.29 & 83 & Ise 1251 & 1.12 \\
\hline 32 & ISe 1674 & 1.74 & 84 & Ise 1254 & 1.85 \\
\hline 33 & ISe 1685 & 2.05 & 85 & Ise 1299 & 1.37 \\
\hline 34 & ISe 1704 & 2.07 & 86 & Ise 1312 & 2.04 \\
\hline 35 & ISe 1725 & 1.22 & 87 & Ise 1320 & 2.09 \\
\hline 36 & ISe 1736 & 1.44 & 88 & Ise 1335 & 1.83 \\
\hline 37 & ISe 1745 & 1.49 & 89 & Ise 1387 & 2.19 \\
\hline 38 & ISe 1762 & 1.62 & 90 & Ise 1400 & 0.62 \\
\hline 39 & ISe 1767 & 1.24 & 91 & Ise 1454 & 0.85 \\
\hline 40 & ISe 1773 & 1.22 & 92 & Ise 1458 & 0.87 \\
\hline 41 & ISe 1789 & 2.3 & 93 & Ise 1511 & 0.8 \\
\hline 42 & ISe 1808 & 1.45 & 94 & Ise 1563 & 2.12 \\
\hline 43 & ISe 1858 & 1.52 & 95 & Ise 1581 & 0.63 \\
\hline 44 & ISe 1859 & 1.69 & 96 & Ise 1610 & 0.49 \\
\hline 45 & Ise 1888 & 1.45 & 97 & Ise 1638 & 1.74 \\
\hline 46 & Ise 2 & 1.22 & 98 & Ise 1647 & 1.93 \\
\hline 47 & Ise 18 & 1.29 & 99 & Ise 1655 & 1.71 \\
\hline 48 & Ise 49 & 1.37 & 100 & Ise 1664 & 1.65 \\
\hline 49 & Ise 90 & 1.33 & Checks & $\begin{array}{l}\text { Korra local } \\
\text { (C1) }\end{array}$ & 1.42 \\
\hline 50 & Ise 96 & 1.62 & & Prasad (C2) & 1.63 \\
\hline 51 & Ise 156 & 0.83 & & $\begin{array}{l}\text { Suryanandi } \\
\text { (C3) }\end{array}$ & 1.78 \\
\hline 52 & Ise 238 & 1.1 & & C4(Ise 375) & 1.9 \\
\hline
\end{tabular}


In conclusion, healthy growth of human body and its functioning is the result of good nutrition (Branca et al., 2015). Anitha et al., 2019 reported that there is significant enhancement in the nutritional value of food when particular millets combined with legumes in 3:1 proportion, as it provides balanced amino acid with good protein digestibility. As cereals are limiting in protein and other micronutrients the study was done with millets and also the essential aminoacids (EAA) can be complemented with each other. Such studies require the profiling of essential aminoacids to choose the type and variety of millet. Thus the present study profiles this critical aminoacid, lysine content in 100 genotypes of foxtail millet. Among these total of 22 genotypes viz., ISe 1181, ISe 1227, ISe 1258, ISe 1286, ISe 1302, ISe 1338, ISe 1547, ISe 1575, ISe 1685, ISe 1704, ISe 1789 , Ise 751 , Ise 771 , Ise 1118 , Ise 1134 , Ise 1137, Ise 1187, Ise 1201, Ise 1312, Ise 1320, Ise 1387, Ise 1563 were found to be Lysine rich genotypes. This study prompts for selecting enriched varieties for household consumption. More over industries can also explore the identified varieties to supplement this indispensable amino acid in preparation and development of products. Millets identified with this essential amino acid can also be exploited for the identification and mining of genes/alleles governing these traits.

\section{References}

Amadou I, Mahamadou E. Gounga and Guo Weile, 2013 Nutritional composition, some health benefits and processing A Review Emirates journal of Food and Agriculture 25(7):501-508.

Anitha. S, Govindaraj. M and Potaka J. K., 2019. Balanced amino acid and higher micronutrients in millets complements legumes for improved human dietary nutrition, Cereal Chemistry. 2019; 97:74-84.
Branca, F., Piwoz, E., Schultink, W., and Sullivan, L. M. (2015). Nutrition and health in women, children, and adolescent girls. British Medical Journal, 351, 27-31.

Chandel, G., R.K. Meena, M. Dubey, M. Kumar, Nutritional properties of minor millets: neglected cereals with potentials to combat malnutrition, Curr. Sci.107 (2014) 1109-1111.

Choi Y, Osada K, Ito Y, Nagasawa T, Choi M, Nishizawa N. Effects of dietary protein of korean foxtail millet on plasma adinopectin, HDL-cholesterol and insulin levels in genetically type 2 diabetic mice. Bioscience, Biotechnology and Biochemistry. 2005; 69:31-37.

He. J.H., T.Y.Yang and G.Z. Wu.2002. Evaluation on nutritive quality of local varieties for foxtail millet in Gansu province. Journal of plant genetic resources. 3:41-44

Kamara TK, Zhu K, Amadou A, Tarawalie T, Zhou H. Functionality, in vitro digestibility and physicochemical properties of two varieties of defatted foxtail millet protein concentrates. International Journal of Molecular Sciences. 2009; 10: 5224-5238.

Muthamilarasan and Prasad. Advances in Setaria genomics for genetic improvement of Cereals and Bioenergy grasses Theoretical and applied genetics, 2015:128(1): 1-14

Sadasivam, S and Manickam, A. 1996. Biochemical Methods. New Age International Publishers, New Delhi.12-34.

Sadasivam, $\mathrm{S}$ and Manickam, A. 1997.Biochemical Methods. New Age International Publishers, New Delhi. 22-23.

Taylor J.N, Schober, T.J., Bean, S. R., 2006. Novel food and Non food uses for sorghum and millets. Cereal Science, 
2006. 44:252-271

Theymoli Balasubramanian and Sadasivam, S (1987) Plant Foods Hum Nutr 3741.

Tian, Z.F., H.P. Wang, Q. Y, Sun, X. Y, Deng, H. Y. Li and C. Yang, 2009. Study of the characteristics and quality of millet and the properties of aminoacid. FarmProd. Proc. 6: 21-22

Upadhyaya, H.D., C.R. Ravishankar, Y. Narasimhudu, N.D.R.K. Sarma, S.K. Singh, S.K. Varshney, V.G. Reddy, S. Singh, H.K. Parzies, S.L. Dwivedi, H.L. Nadaf, K.L. Sahrawat, and C.L.L. Gowda. 2011. Identification of trait-specific germplasm and developing a mini core collection for efficient use of foxtail millet genetic resources in crop improvement.

Vadivoo. A.S. R. Jodreph and N.M.Ganesan, 1998. Genetic variability and diversity for protein and calcium contents in fingermillet (Eleusine coracana $(\mathrm{L})$ Gaertn) in relation to grain color. Plant Foods Hum. Nutr. 52:353-364.

Zhu, Z.H., W.X, Li FLiu, X.F. Zhang, S.C. Liu, Y. Li and W.Z. Wang 2004. Identification and evaluation of quality traits in millet germplasm. Rain fed Crops 24: 329-331.

\section{How to cite this article:}

Sandhya, M., J. V. Ramana, D. Ratna Babu, V. Padma and Vijaya Gopal, K. 2020. Evaluation of Foxtail Millet [Setaria italica (L.) Beauv.] Germplasm for Lysine Content. Int.J.Curr.Microbiol.App.Sci. 9(11): 1910-1915. doi: https://doi.org/10.20546/ijcmas.2020.911.226 